\title{
MANAGING VALUES
}




\title{
MANAGING VALUES
}

\section{ETHICAL CHANGE IN ORGANISATIONS}

\author{
Paul Griseri
}

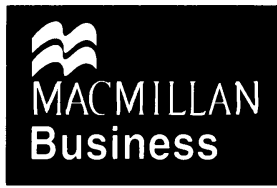




\section{$2 \pi$}

(C) Paul Griseri 1998

Softcover reprint of the hardcover 1st edition 1998 978-0-333-71106-4

All rights reserved. No reproduction, copy or transmission of this publication may be made without written permission.

No paragraph of this publication may be reproduced, copied or transmitted save with written permission or in accordance with the provisions of the Copyright, Designs and Patents Act 1988, or under the terms of any licence permitting limited copying issued by the Copyright Licensing Agency, 90 Tottenham Court Road, London WIP 9HE.

Any person who does any unauthorised act in relation to this publication may be liable to criminal prosectuion and civil claims for damages.

The author has asserted his rights to be identified as the author of this work in accordance with the Copyright, Designs and Patents Act 1988.

First published 1998 by

MACMILLAN PRESS LTD

Houndmills, Basingstoke, Hampshire RG21 6XS

and London

Companies and representatives

throughout the world

ISBN 978-0-333-71107-1 ISBN 978-1-349-26419-3 (eBook)

DOI 10.1007/978-1-349-26419-3

A catalogue record for this book is available

from the British Library.

This book is printed on paper suitable for recycling and made from fully managed and sustained forest sources.

$\begin{array}{llllllllll}10 & 9 & 8 & 7 & 6 & 5 & 4 & 3 & 2 & 1\end{array}$

$\begin{array}{llllllllll}07 & 06 & 05 & 04 & 03 & 02 & 01 & 00 & 99 & 98\end{array}$

Editing and origination by

Aardvark Editorial, Mendham, Suffolk 


\section{Contents}

Acknowledgements vi

Introduction vii

PART I UNDERSTANDING AN ORGANISATION'S VALUES 1

1 Discovering People's Values 3

2 The Dishonest Manager 26

3 My Values - Other People's Values 44

4 The Myth of Shared Values - Organisational Totalitarianism 66

$\begin{array}{ll}\text { Conclusion to Part I } & 87\end{array}$

$\begin{array}{lll}\text { PART II AGREEING AND CHANGING VALUES } & 89\end{array}$

5 Personal Moral Skills 91

6 Value Rigidity 112

7 Consistency and Sympathy 129

8 Highest Common Denominators 142

Conclusion to Part II 158

PART III MAINTAINING AN ORGANISATION'S VALUES 159

9 Organisational Principles and Codes 161

10 Process, Result and Reward 175

11 How Stakeholders Learn an Organisation's Values 189

12 Ethics as its Own Worst Enemy 204

Conclusion $\quad 219$

Bibliography $\quad 221$

Index $\quad 225$ 


\section{Acknowledgements}

I have been thinking about some of the subjects of this book for some years, and many people have unwittingly contributed to my ideas, sometimes through extended discussion, sometimes through stray comments made in desultory conversations which in one way or another have sparked something off. In one or two cases these go back decades rather than years. The list is probably endless, but I would like to mention in particular the following people: David Arbus, Tony Emerson, Maurice Green, David Langlois, Richard Pettinger, Tony Skillen, Norma Williams and Andrew Wright. Others have helped me in more formal ways. Most notable are Jon Groucutt, who read the manuscript in draft and made many helpful suggestions, and Chris Cherry, who was my doctoral supervisor at the University of Kent, now some ten years ago. I would like also to thank Sue Proudfoot who, as my line manager at London Guildhall University allowed me time to complete this book.

I am also grateful to a large number of individuals who have given up their time to be interviewed by me - as I have always guaranteed anonymity in all such interviews I can only here thank you all anonymously. In similar vein I would like to thank the very many participants of management programmes, most notably MBA (Master of Business Administration) students, who have discussed some of the ideas of this book in the course of their studies - sometimes quite inadvertently. You have all contributed to my thinking far more than you realise.

I am indebted to the editors of Business Ethics: A European Review for the permission to reproduce material originally published in that journal (October 1994) as part of Chapter 7.

My biggest thanks are to my partner Lyn Thompson, who has supported and encouraged me throughout the time I have been working on this, as indeed she always does. This is an immeasurable debt for which I am continually grateful. 


\section{Introduction}

Business and values are inextricably linked. We have shared values, value driven, corporate values, professional ethics, managerial ethics, and other ideas, all pressing in their different ways on managers and organisations. A plethora of books and articles has been written on ethics and values in organisations. Most of these focus on the 'what' of value management. They look at what values should be adopted and implemented by organisations. They talk about honesty, integrity, equality and so on.

The great gap here is the 'how'? Managers talk about values and ethics some practice these, many don't. Does this make the latter immoral? Given that we all have pretty good ideas about what we think is right or wrong, how is it that we don't all act ethically, every day, all day?

This book focuses on some of these 'how' questions. It is as much about behaviour in organisations as it is about ethics. It looks at the underlying issues surrounding changing the values and behaviour of individuals. By and large, the view outlined here is sceptical. The idea of managing values, in the sense of exercising a clear and planned influence over what people feel is right or wrong, is misplaced. I don't say you can't do it, but it is much more complex than would seem at first sight. Much of this book is devoted to showing the kinds of complexity. Each individual's value set is incredibly complicated, and idiosyncratic. Not only is it difficult to work out what someone really values, it is also difficult to make any sensible comparisons with other people's values. If we had vast reserves of time then we might be able to collect the information and make sense of it. But managing in organisations is a highly time-critical activity. So for all practical purposes the idea of managing values is not feasible. Most of the book explains and justifies this. A central part of the argument is that hearts and minds are impossible to disentangle. Values are a combination of cognitive and emotive factors.

So what can we do? Essentially the message here is that the most effective managerial strategy is to accept this practical limit to understanding values and treat it is a positive feature rather than as an absence of control. This has important implications. Many of the managerial presumptions relating to values need to be stood on their head. For example:

unshared values are a vital resource to an organisation

- agreement is sometimes undesirable 
- resistance to change should sometimes be encouraged

- often a person does not have a single stable value set at all

- we are mainly ignorant of the key elements of a person's values

- honesty is not always the best policy, sometimes it's not even a possible one

- we often don't really understand our own values

- rewarding good behaviour can undermine a person's values

- codes of ethics are often dead material, of questionable use for managing values

- 'business ethics' as a set of ideas is almost counterproductive.

These may seem challenging, but they all come out of a dispassionate analysis of values and motives. The key to the argument is that many ideas, such as eliminating resistance or sharing values, are mistakenly treated as paradigms, model solutions to organisational issues. In reality they all have limitations, based on context, information or other elements.

Very rarely here will you see statements that something is always or never appropriate. The vast amount of the text states that sometimes certain things may occur, or that other things don't necessarily happen. The approach I have adopted is to try to emphasise how varied the possibilities are, and hence how difficult it is for managers to make definitive choices on the narrow base of ideas which are proposed by organisational theorists. Of course, there are many situations in organisations where it is much better to do something, however poorly evidenced, than nothing. This point is recognised and accepted throughout the book. Nevertheless, it is important to acknowledge that it is acting without a firm footing. The worst error of all is to mistake a shot in the dark for a soundly based strategy.

A few words about the style of this book. The material comes from several sources. Much of it is derived from issues and incidents recounted to me by professional managers, in MBA or similar classes, in interviews, or in management development sessions. As a point of principle I always give complete confidentiality to material given to me, whether in writing, in an open discussion or in a private interview. So all cases and examples discussing individuals and organisations have been made into 'faction' - true in essence, and usually deriving from specific cases, but altered and amended to remove any trace of the real life source.

A large amount is also based on reflection and conceptualisation, relating to existing theoretical ideas but often going beyond these. Most of the book reflects a synthesis of material from these and other sources. Existing theories are mentioned and discussed, and novel ones are also introduced, but at all times the intention has been to keep a steady focus on the needs of practising managers. 
I have tried to present ideas in terms as simple as is consistent with making a point clearly. This still can result in some difficult passages! But they are difficult because I have found it impossible to express them any more easily. Please bear in mind that the difficult material, as much as the easy, is there because it is important to the argument. There are no chapters or sections put there to fill the writing out. Everything in the main text is theory, argument, discussion, example. I have tried to pull specific material out into boxes. More extended explanations of the theories of other writers have been treated mainly in this way, as have some of the fuller cases and examples. This should help readers to follow the flow of the main text, and skip things they already know or move on when they feel they don't need further examples. As I hope this text will be useful on post-experience management programmes, such as the MBA, I have included questions at the end of each chapter for consideration and discussion.

A last point on style: values are heavily integrated into many other facets of people's personality and behaviour. The ideas in the book have to be laid out in a linear fashion, because that's how we read, but inevitably there are crossings over, and references forward and back. Some of these are flagged up, but some are implicit - indeed, readers might well see other connections that have not occurred to me.

The book is broken into three parts, each of which has four chapters. Part I, 'Understanding An Organisation's Values' presents the main elements of my scepticism over managing values. Chapter 1 argues that values are complex and so it's simply very difficult in practice to identify what values someone really holds. We begin to see the analysis of an individual's values as based on what they explicitly say and what may underlie this. Chapter 2 takes one example, that of honesty, and demonstrates how difficult it is to be sure what this really means for managerial action in concrete situations. Sometimes it is clear that all options for action may violate some of the concerns relating to honesty. Chapter 3 explores further the idea of understanding values, this time from the point of view of how a manager can differentiate between recognising what other people value as opposed to evaluating their behaviour on his or her own values. How far can we set aside our own preconceptions and look afresh at other people's views? Chapter 4 looks more directly at the idea of shared values, and indicates the potential dangers with this.

Part II, 'Agreeing and Changing Values' focuses on some of the elements relevant to value change. Chapter 5, 'Personal Moral Skills' looks at the capabilities within an individual for change. In Chapter 6 'Value Rigidity' we examine in more detail the difference between what someone says they value and what underlies this. People's value sets start to look something like an iceberg, with a small visible set of explicit values and a large and generally unexplored underlying complex. We also see the kinds of resistance 
people have to value change - and that this is often no bad thing. As an indication of the way in which this may affect how values are managed in an organisation, Chapter 7 'Consistency and Sympathy' looks at how two ideas can function as triggers for value change. Chapter 8, 'Highest Common Denominators' pulls together the iceberg idea and the rigidity metaphor. Amongst other things, we see that ideas such as tolerance and being flexible have their negative side. In Part III, 'Maintaining an Organisation's Values' we turn to some aspects of management practice. Chapter 9, 'Organisational Principles and Codes' analyses how and why codes exist in organisations, and how easily they can degenerate into lifeless documents that bear no relation to what the members of the organisation really feel. Chapter 10 'Process Result and Reward' follows up this with a discussion of what gets brownie points in an organisation - good behaviour, not necessarily the right values. This emphasis on outcomes and behaviour, and the reward strategy which can often accompany it, is often highly detrimental to values. In Chapter 11, 'How Stakeholders Learn an Organisation's Values' we look at the real learning process in an organisation - which is not the official one. People learn compulsively all the time, whether they realise this or not, so managerial action is a prime vehicle of what people will percieve as the real value set of the organisation rather than what is stated. In Chapter 12 'Ethics as its Own Worst Enemy' we turn away from organisations to the management development industry. What we shall see is that the proliferation of ideas and models, and the influence of consultants and gurus is not generally positive - managers can lose the sense of self-reliance which is so crucial for their development, and ethical ideas can be imposed on organisations rather than created within them.

Although much of the work is critical and sceptical, this is not intended to be a negative book. By lifting the veils of illusion, maybe we can get to celebrate the reality underneath. The reality is at once far more complex, but also far more suggestive of opportunities and novelties than most of us generally believe. Hearts and minds come in many shapes and sizes, and we learn an enormous amount just by recognising this and taking it in. I hope you find this both an interesting and a useful book. 